\title{
THE IMPACT OF COMMUNICATION FUNCTION ON THE ORGANIZATION IN JORDAN
}

\author{
A.H. Alhroot ${ }^{1^{*}}$ \\ *1PhD Tourism Marketing Department of Marketing, Collage of Economics and Business, \\ Alzaytoonah Unveristy of Jordan, P.O.Box 130, Amman 11733, Jordan \\ E-mail: alhroot2007@googlemail.com
}

*Corresponding Author: -

Email: alhroot2007@googlemail.com

\begin{abstract}
: -
This study is to identify the impact of communication function in the organization. Thus, this case study was the impact of the communication function on the organization's operations. Therefore, in order to examine the challenges facing managers in an attempt to communicate with staff from various departments in the organization. The survey questionnaire system design used random sampling technique of size 260, which includes 20 senior staff, 40 subordinates and 200 belonging to them. Also, a total of 260 questionnaires of collect data are secondhand.

The preliminary data collected using the analysis tables indicating the proportion of respondents. Therefore, chi-square analysis has been used to reach conclusions and summary. Finally, the study is measured the impact of communication function on the work of the organization to achieve its goals.
\end{abstract}

Keywords: - organization, communication, function, Jordan, preliminary data

\section{(a) $(\$)$}




\section{INTRODUCTION}

Communication is defined as transmitting, receiving and processing information. Thus, components of communications that include: sender, encoding processes, transmission device, decoding, receiver, feedback and noise (Clow\&Baack, 2013). The transcript uses shoe firms and the ad to reveal how communication obtains between them and their customers (Beakbane, 2013). Some websites of selected shoe firms such as that include:

1-New Balance (http://www.newbalance.com),

2-Reebok (http://www.rbk.com),

3- ASICS (http://www.asics.com), and

4- Skechers (http://www.skechers.com).

Also, the knowledge of the way and means of message that enables communications officer to get the best training in the process of sustainable development of the organization. But more importantly, it involves understanding the idea of transformation that moves them in the intended direction. Thus, the intent is to remind everyone who works in the organization to improve the rules of conduct and not to build resentment. It is important to know how and when and what is said. According to Dunham et al. (1989), effective communication occurs when the information or data received from the sender to the receiver is designed to transfer the correct information be required. At the same time, the implementation of planning, organizing, directing and controlling the personnel management process managers is to reach the organization's aims. Thus, this means that managers must communicate to be able to managerialaction that leads to the accomplishment of the objectives of the association's performance.Also, without communication directors cannot implement the management process, hence the aims of the association cannot be efficiently attained. It is through the exchange of information, the managers become alert of the needs of customers, the public and stakeholders. Thus, the accessibility of suppliers and claims of shareholders and the regulations of the government and community concerns are to be important practical survey for the communication function in the organization (Nongo, 2005).

Today, most of the communications and public relations managers dealing with the problems of the communication process on a daily basis, which requires proper attention and time from the director.This is what makes organizations / companies used time and resources to correct messages, content policies and guidelines to achieve the organization's aims. As a result, the hypotheses of this study aim to do communication on organizational efficiency in the association (Alhroot, 2014). Accordingly, the connection is in any organization is difficult and subject to misunderstanding because the message is often complex. For example; sending messages with encoding processes are to receive them in terms of differences between sender and receiver (Jerry, 1980). These problems arise from working with methods, ideas and attitudes than it was in the past. Veterans in the organization absorb information to deal with the collapse of communications, the waste of time and resources in the context of explaining some of these ideas to the public. The complexity of the message is related to disputes about the content, nature of the difficult working conditions and the noise that is inherent in the organization environment. Abilities words and terminology are considered that talk about who specialize in high-tech communications contained a message from the sender to the recipient may show slight differences in meaning. The directive, which appears quite clear it may seem confusing to the receiver (AL-Amaireh, 2014).

As a result, it may be the coming out of systematic information these doubts largely on the efficiency of the effect inthe workplace and make it even more difficult for managers to accomplish the aims. Accordingly, this study examines the impact of the communication function on the competence of the organization and gives a general introduction to the subject under study (Alhroot, 2014).

\section{Related Work}

The challenge for marketers in the future has to do with the collection of information by modern means of communication (Relwani, 2012). Although, filtering through the huge number of statistics, ideas, messages that put them together in the form of a clear to the leaders of the company for the study. Accordingly, the technology allows the function of instant communications between businessmen and workers in the business organization worldwide (Isaacs, et al, 2002). Marketers can rapidly decide who is buying a firm's products and recognize the best communication channels to reach those customers. The Internet and the accessibility of information technology have moved more power to the client (Stanonik,2013). Both individual customers and businesses can shop online and even place orders without ever visiting a retail store.

In accordance with other authors caution business professionals to evade communication cycles that underlines talking over listening (Taylor, 1989). Thus, emails have streamlined flow communication function in many associations, but it also provides the employees in taking their opinions on the performance of these organizations. Managers of communication who make extra time to listen to the concerns and the ideas of their teams often succeed in attaining organization's goals for building highly collegial environments in which to operate (Cox, 2010).

Since clients can buy goods and services from anywhere in the world. Therefore, the communication function plays an important role in such an environment and advertising built-in marketing communications enough to keep the market share and competitive advantage for the sales organization (Brulle, 2010). Also, the competition may come from a company in another country. In this kind of mature markets, the communication function in the company has one method that can get sales to take customers away from other companies. This means the fact that many products have almost identical benefits from the consumer's perspective (Lasswell, 2007). This means that shoppers want to buy from a range of brands are accepted instead of a single specific brand. In response, marketers must create messages reflect a clear difference. In essence of communication function must work to build the type depend on the superiority of the 
company's brand and its products or services? (Vicker, 2008). Customers are able to integrate information they receive from a variety of sources.Also, this means marketers should be concerned about integration (Pedersen, 2014). However, for every contact point should plan the same communication. This means that contact points are the sets for the customer may cooperate with or obtain added information about a firm. The application on the impact of communication function in the modern business organization; Van DVDs, VCRs and other devices make it possible to watch shows without commercials. Resulting in a decrease in the effectiveness of media advertising and rising popularity of cable TV and satellite dishes, which means consumers have a wider range of viewing options. As a result, the number of people who use the major national networks declined. Therefore, the IMC programs are trying to help companies in order to go beyond the difficulty of access to consumers (Borislav, 2011).

\section{III.Text Inpainting}

\section{Objectives of the Study}

These aims of this study are:

a- To inspect the application of communication function in the organization work.

b- To ascertain the influence of the media / communication methods that improving function in the work of business organizations.

c- To check the various challenges that manager's face in communicating with the workers in different sections within the organization.

d- To examine the impact of communication's role on the performance of the organization.

e- To explore integrated marketing with communication function over the organization.

\section{2- Hypotheses of the Study}

Ho1: Communication function is not applicable to the organization work.

Ho2: There are no methods and means for communication function to improve the operation of the organization.

Ho3: There are no challenges with relation facing managers in an attempt to communicate with employees in different departments in the organization.

Ho4: In attendance is no impact of communication's function on the performance of the organization.

Ho5: There is no integrated marketing with communication function in the organization.

\section{IV.Experimental Results}

The quantitative research is utilized statistical methods that are used explanatory statistics to take out the arithmetic mean and standard deviation. Thus, the questionnaire was analysed using a range of statistical analysis packages (spss) collected from a sample of the study as shown in tables $(1,2$, and 3):

\section{1- Testing the Hypotheses:}

The results of statistical analysis in table 1 showed regression testing of the hypotheses. As well, in this study that the being there of a statistically significant outcome. As a result, that the correlation coefficient $\mathrm{R}$ is $(0.815)$, while the coefficient of purpose R2 reached (0.567).

Table 1: Regression Testing of the Hypothesis

\begin{tabular}{|c|c|c|}
\hline Item. No & Regression testing & Rustles \\
\hline 1. & The level of significance & .0215 \\
\hline 2. & Coefficient selection of R2 & .567 \\
\hline 3. & Connectivity & .815 \\
\hline 4. & Favouritism & 2.431 \\
\hline 5. & Tabularized & 1.867 \\
\hline 6. & As a result of hypothesis nihilism & Rejection \\
\hline
\end{tabular}

Thus, this effect is enhanced significantly up the value of favouritism, which amounted to (2.431), the largest of tabulated value (1.867). Also, statistically significant on the level of (0.0215); the level is less than the specified value of 0.05 . Thus, the alternative hypothesis accepts and rejects the hypothesis negativism. This means that there is the impact of communication function on the organization in Jordan.

\section{2- Variables of the Communications Function}

Table 2 is shown that variables of the communications function are measured. Besides, the fashions in the research sample were positive all the questions about the study, because the arithmetic averages greater than the average measurement tool 3.5. 
Table 2: Variables of the Communications Function

\begin{tabular}{|c|c|c|c|}
\hline $\begin{array}{c}\text { Item } \\
\text { No }\end{array}$ & Changeable & $\begin{array}{l}\text { Arithmetic } \\
\text { Mean }\end{array}$ & $\begin{array}{l}\text { Stand } \\
\text { Deviation }\end{array}$ \\
\hline 1. & $\begin{array}{l}\text { Function of communication is the foundation of a process of } \\
\text { development for good service to the customer. }\end{array}$ & 4.59 & 0.891 \\
\hline 2. & $\begin{array}{l}\text { All means of communication function in the organization is } \\
\text { followed the needs and wants of the customer. }\end{array}$ & 4.05 & .978 \\
\hline 3. & $\begin{array}{l}\text { Moving of contact system function in organization is activated } \\
\text { of integrated marketing communications in global market. }\end{array}$ & 3.99 & 1.17 \\
\hline 4. & $\begin{array}{l}\text { Well qualified of communication workers are dealt with the } \\
\text { challenges that manager's face within the organization. }\end{array}$ & 4.52 & .890 \\
\hline 5. & $\begin{array}{l}\text { Tangible high quality service of the communication's function } \\
\text { will attract clients to repeat their visit. }\end{array}$ & 3.95 & 1.09 \\
\hline 6. & $\begin{array}{l}\text { Potential customers can contact with the function of } \\
\text { communication channels by building special relations. }\end{array}$ & 4.10 & .969 \\
\hline 7. & $\begin{array}{l}\text { The reaction of customers will be after having service by } \\
\text { contact function }\end{array}$ & 3.85 & $1: 11$ \\
\hline 8. & $\begin{array}{l}\text { Marketing ofcommunication functionwill bring lasting } \\
\text { customers. } \\
\text { The administration proves on the importance of positive } \\
\text { communications function with customers. }\end{array}$ & 4.39 & .893 \\
\hline \begin{tabular}{|c|} 
\\
Item
\end{tabular} & $\begin{array}{c}\text { Reward working employees in communication is to build a } \\
\text { Variables }\end{array}$ & \multicolumn{2}{|c|}{\begin{tabular}{l|l} 
Arithmetid Standard
\end{tabular}} \\
\hline 10. & $\begin{array}{l}\text { homogeneity for all. } \\
\text { Customer's contact is to hold the chances for enhancing } \\
\text { common trust. }\end{array}$ & 4.42 & .959 \\
\hline 11. & $\begin{array}{l}\text { Developing good programs of communications function are to } \\
\text { set up relations with the customers eternally. }\end{array}$ & 3.96 & 1.022 \\
\hline
\end{tabular}

Furthermore, the variables have 11 dependent and independent changeable, which are ranked between a low of mean 3.85 (The reaction of customers will be after having service by contact function) to a high average of 4.59(Function of communication is the foundation of a process of development for good service to the customer).

However, these variables are consistent for concerning the function of communications in the organization. Also, the dependent variable (Function of communication is the foundation of a process of development for good service to the customer) represents the output, which is tested to see if it is the effect. The independent variables represent the inputs, which are tested to see if they are the cause. Consequently, the analysis test in this study showed that the dependent variable is the outcome, while the other independent variables are the reason such as (Tangible high-quality service of the communication's function will attract clients to repeat their visit).

\section{C-The degree of Reliability}

In this context test was used (Cronbach's alpha) to measure the stability of the 9variables that related to the level of performance of communication functions. Moreover, the value of (alpha) 89\%, which is very good being higher than the rate at which an acceptable return of $60 \%$.

Table 3: The Arithmetic Mean and Standard Deviation Variables Related to the Level of Performance of Communication Functions

\begin{tabular}{|r|l|l|l|}
\hline No & \multicolumn{1}{|l|}{ Mean } & Deviation \\
\hline 1. & $\begin{array}{l}\text { Communication function of performance locates the organization in a } \\
\text { superior cut-throat position. }\end{array}$ & 3.90 & 1.05 \\
\hline 2. & $\begin{array}{l}\text { High-quality of communication function in the organization can benefit } \\
\text { from external events. }\end{array}$ & 3.88 & 1.07 \\
\hline 3. & $\begin{array}{l}\text { Good service of communication function is added to best decisions for } \\
\text { the organization. }\end{array}$ & 4.15 & .909 \\
\hline 4. & $\begin{array}{l}\text { These variables of good performance in communication function are the } \\
\text { straighten combined attempt towards the desired results. }\end{array}$ & 3.75 & 1.11 \\
\hline 5. & $\begin{array}{l}\text { Finest function of communication is contributing to the growth of the } \\
\text { organization. }\end{array}$ & 3.79 & 1.06 \\
\hline 6. & $\begin{array}{l}\text { Qualified training workers of communication function assists in } \\
\text { providing human resources at the right time. }\end{array}$ & 3.97 & 1.19 \\
\hline 7. & $\begin{array}{l}\text { Outstanding performance of communication function provides money } \\
\text { conditions. }\end{array}$ & 3.87 & 978 \\
\hline 8. & $\begin{array}{l}\text { Communication performance function in the organization brings its } \\
\text { customers to it. }\end{array}$ & $3: 89$ & $1: 22$ \\
\hline 9. & $\begin{array}{l}\text { Improved the performance of communication function gives it a } \\
\text { competitive advantage. }\end{array}$ & 4.11 & .890 \\
\hline
\end{tabular}

It is noted from Table 3 above that those tendencies in the research sample were positive to all the questions about the study. Consequently, the arithmetic means is greater than the average measurement tool 3.5 . 


\section{Conclusion}

This study at the end of this research will be important for the public / general government. Because it will bring out the true picture of the world of organizational communication function to enable people present ideas clearly and convincingly. Also, the study guides the work of the department / institution managers of the methods and means of communication function better. Thus reducing the spread of personal conflicts, enhance productivity, create an open organization in the interest of the development of creativity and self- restraint among the members of the organization. Again, this study will be important for the staff and the communication function of the challenge that will put them in on what to do if the organizations aim to achieve goals.

Accordingly, this makes appropriate plans to improve performance so that attained the goals and objectives of the organization and the stakeholders. This study will provide relevant information to assist them to make re-assessment of their interest in a case. Also, the research would contribute to academic knowledge upon the impact of communication organizational and provide information and useful findings to organization.

Therefore, this study reached the following recommendations:

1- Communication function is valid to the organization work.

2- The methods and means for communication function are to enhance the process of the organization.

3- The qualified employees of the communication function are dealt with the defys that facing managers in an attempt to communicate with in different departments in the organization.

4- Communication's function is affected of on the performance of the organization.

5- The integrated marketing with communication function affects all of a firm's commerce-to-business, selling channel, and client hubed and internally directed communications.

\section{Future Implications}

This study shows the relevance of communication function to organization and its tools through the development of a classification model phases of the organization history. This model can be used universally in documenting the various fields of communication function as well as the theories of scientific knowledge. However, the following proposals for future research, which are to:

1- Utilize all means of communication tools for improving the services of the organization work efficiency.

2- 2-Put forward the bases of communication function that developed in this study for other challenging nationwide business industry.

3- Effective leaders must learn how to match appropriate communication styles to company norms that use more formal methods of communication between managers and employees.

4- Use this study in any country as a frame model for the development of communication function in the organization.

5- Adoption of this study is to strengthen the communication function in the firms simulates the global organizations from the perspective of practical scientific research tangible for the first time of its kind.

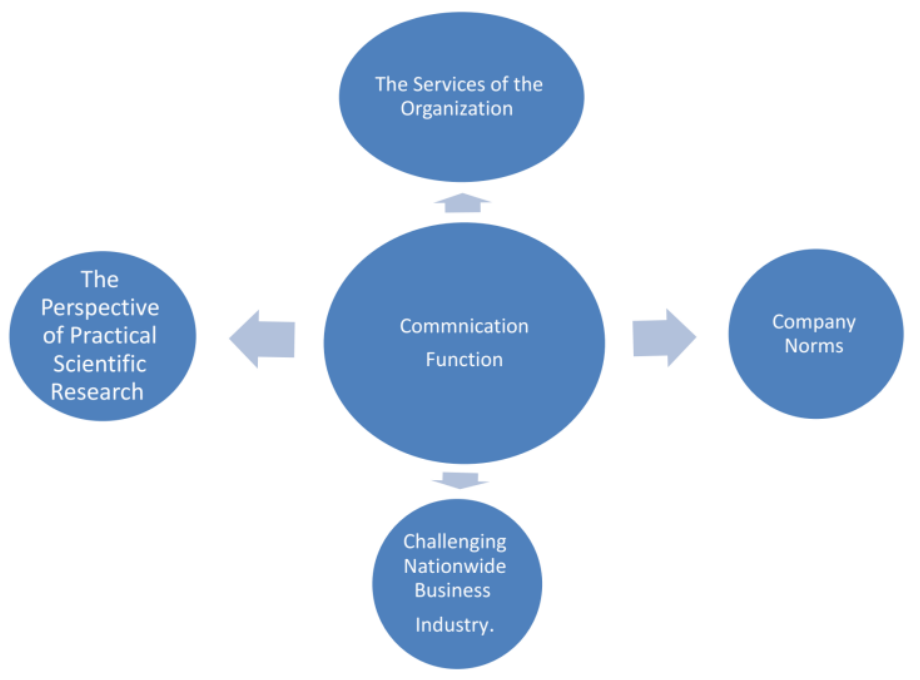

Figure (1) Model of the Impact of Communication Function in the Organization

\section{References}

[1].AL-Amaireh, A.F. (2014). Measuring the Impact of Pub+lic Relations Function on the Performance of the Jordanian Hotels.International Journal of Innovative Research in Science, Engineering and Technology.http://www.ijirset.com

[2].Alhroot, A.H. (2014). Launching Marketing of Facilitated Tourism to Access Them Globally by Jordan.

[3].European Journal of Business and Management.www.iiste.org 
[4].ISSN 2222-1905 (Paper) ISSN 2222-2839 (Online). Vol.6, No.12, 2014.

[5].Alhroot, A.H. (2014). Jordan's Tourism Industry Development from Traditional Era to the Digital Age. European Journal of Business and Management. www.iiste.orgISSN 2222-1905 (Paper) ISSN 2222-2839 (Online) Vol.6, No.3, 2014.

[6].Andrews, D.C. and W.D. Andrews.(1988). Business Communication. New York: Macmillan.

[7].Beakbane, Tom (1 June 2013). "Four reasons why marketers should care about integration". Integrated Brands. Retrieved 5 February 2014.

[8].Borislav, K. (2011). Application of E-Business in Modern Operation of Public Companies in Serbia. International Journal of Business Administration Vol. 2, No. 3; August 2011. www.sciedu.ca/ijba 32 ISSN 1923-4007 E-ISSN 1923-4015.

[9].Brulle, R. J. (2010). From Environmental Campaignsto Advancing the Public Dialog: Environmental Communication for Civic Engagement. Environmental Communication: A Journal of Nature and Culture, 4, 82-98.

[10]. Clow, K. E. \&Baack, D. E. (2013). Integrated Advertising, Promotion, and Marketing Communications, 6/EISBN10: 0133126242 - ISBN-13: $9780133126242 @ 2014$. Prentice Hall. Paper, 480

[11]. pp.Published 02/04/2013・Instock

[12]. Cox, Robert. (2010). Environmental Communication and the Public Sphere (2nd ed.). Thousand Oaks: Sage Publications.

[13]. Ellen Isaacs, Alan Walendowski, Steve Whittaker, Diane J. Schiano\& Candace Kamm. (2002).The Character, Functions, and Styles of Instant Messaging in the Workplace. AT\&T Labs, 180 Park Ave., Florham Park, NJ 07932 ellen@izix.com,walendo@ bitsmith.com,stevew@ research.att.com,schiano@ac. org, cak@ research.att.com.

[14]. Joe Taylor Jr, Demand Media. (1989). Organizational Structure \& Communication. http://smallbusiness.chron.com/organizational-structure-communication-3815.html.

[15]. Lasswell. Harold D.( 2007). The Structure and Function of Communication in Society. İletişim Kuramve Araştırma Dergisi. Say 24 Kış-Bahar 2007, s.215-228.

[16]. Mitra, Barun K. (2006). Effective Technical Communication. New Delhi: Oxford University Press. Mitra, Barun K. (2006). Effective Technical Communication. New Delhi: Oxford University Press.

[17]. Nongo, s. (2005). Fundamentals of Management, Makurdi, Aboki Publishers Economic and Financial Crimes. (2011): Annual Report and, Abuja,Academic Press Plc.

[18]. Pedersen, Tim. (2014). Data Integration in Programmatic Campaigns: Vary Your Sources. Thursday, October 30, 2014.

[19]. Relwani, Jessi. (2012).What is the various means of communication available in modern India? http://www.preservearticles.com/201012251643/means-of-communication.html.

[20]. Rizvi, Ashraf M. (2005). Effective Technical Communication. New Delhi: Tata McGraw-Hill.

[21]. Rutherford, Andrea J.(2001). Basic Communication Skills for Technology. New Delhi: Pearson Education, Asia.

[22]. Stanonik,R.(2013).BestPracticesto Create an Effective Internal Communications Plan to Improve Profits.Posted on October 10, 2013 in Marketing, Tork Better Business in Office Buildings.

[23]. Vicker, B. (2008). Communicative Functions or Purposes of Communication. The Reporter, 14(1), 13-17. See more at: http://www.iidc.indiana.edu/?pageId=508\#sthash.z3V6QHOh.dpuf. 